\title{
Global Issues and Financing for Achieving Sustainable Development Goals
}

\author{
Unmana Sarangi ${ }^{1 *}$
}

${ }^{1}$ Government of India, INDIA

*Corresponding Author: usarangi68@gmail.com

Citation: Sarangi, U. (2020). Global Issues and Financing for Achieving Sustainable Development Goals. Dutch Journal of Finance and Management, 4(1), em0062. https://doi.org/10.29333/djfm/8398

\section{ARTICLE INFO}

Received: 6 Jun. 2020

Accepted: 29 Jun. 2020

\begin{abstract}
The research paper entitled 'Global Issues and Financing for Achieving Sustainable Development Goals' is a unique research effort to analyze the current frontline global issues that is affecting the global economies at large. In these days of current global crisis, the COVID-19 global pandemic has emerged as not only a global health crisis but also a global humanitarian crisis. The research has made an attempt to study and analyze the cross cutting global issues including the present global pandemic which has taken a serious toll on humanity, but has also affected the various sectors of the global economies such as health, humanitarian, economic, social, geopolitical, environment etc., and other related cross-cutting issues which are vital determinants and key indicators in achieving the Sustainable Development Goals(SDGs). The paper also dwells into the aspect of global financing issues keeping in mind and including finding ways and means for containment of the present global health pandemic by looking into the various aspects of financing needs of the economies to enable these economies to come out of such serious economic shocks that has resulted and affected these economies due to the severe outbreak of COVID-19. The research paper also covers and studies other aspects of the global economies such as the Addis Ababa Action Agenda(AAAA) on cross cutting initiatives to develop and built-in synergies for achieving the SDGs, monitoring by the Inter-Agency Task Force on Sustainable Development and the Financing for Global Sustainable Forum(FfSD), upcoming events planned by FfSD, Global issues for FfSD Forum, ECOSOC and its role on International Cooperation in Tax Matters, Global Economic Governance, External Debt, Innovative Financing for Sustainable Development including Inclusive and Local Finance, Global Investors for Sustainable Development Alliance, key messages conveyed by the United Nations in their report on Financing for Global Sustainable Development 2020, important statements made by global experts of United Nations on issues pertaining to financing for achieving SDGs, COVID-19 and it impact on humanity in terms of human crisis, global health crisis and concerns, socio-economic and environmental aspects for sustainable long-term financing in various economies including the undeveloped LLDCs, SIDSs, African \& Caribbean economies and the developing economies. The role of international multilateral institutions such as the World Bank, IMF, IFC, MIGA and other global financing institutions are of paramount importance in terms of financing these economies to come out of the global pandemic at the first instance and then in stabilizing these economies in the long-run. The important policy considerations and conclusions drawn from the research study is that the WHO and United Nations including other multilateral and financing institutions need to work in tandem not only to aid these economies to come out of the global pandemic, but also to strike a balance in terms of achieving the long-term SDGs slated by UN which are key indicators and determinants in achieving the SDGs in these economies.
\end{abstract}

Keywords: COVID-19 pandemic, SDGs, FfSDR, International Tax Cooperation, Global Investors Sustainable Alliance, Global Aspirations

\section{INTRODUCTION}

The Addis Ababa Action Agenda (AAAA) adopted by United Nations contains several key cross-cutting initiatives that build on the synergies of the Sustainable Development Goals (SDGs) and address critical gaps in their delivery. Crosscutting issues and commitments in the Addis Agenda, include: (i) the delivery of social protection and essential public services for all; (ii) scaling up efforts to end hunger and malnutrition; (iii) establishing a forum to bridge the infrastructure gap; (iv) promoting inclusive and sustainable industrialization; (v) generating full and productive employment and decent work for all; (vi) protecting ecosystems; (vii) promoting peaceful and inclusive societies; (viii) gender equality and the empowerment of women and girls; (ix) children and youth; (x) countries in special situations; and (xi) the global partnership for sustainable 
development. Each of these initiatives can contribute to progress across a large number of SDGs. Because of the close links to the 2030 Agenda for Sustainable Development, monitoring by the Inter-Agency Task Force set up by United Nations will be able to draw on a large number of relevant SDG indicators, in particular for commitments focused on achieving specific outcomes. The Task Force will add to those as necessary, and also provide greater specificity and detail to the monitoring of financial and non-financial means of implementation (MoI) (Source: Addis Ababa Action Agenda of the Third International Conference on Financing for Development, United Nations, New York, 2015).

\section{ADDIS ABABA ACTION AGENDA}

\section{MONITORING (Source: Addis Ababa Action} Agenda of the Third International Conference on Financing for Development, United

\section{Nations, New York, 2015)}

The following salient features of Addis Ababa Agenda are being monitored by the United Nations viz;

- Delivering social protection and essential public services

- Ending hunger and malnutrition

- Closing the infrastructure gap

- Promoting inclusive and sustainable industrialization

- Generating full and productive employment for all

- Protecting ecosystems

- Promoting peaceful and inclusive societies

- Gender equality

- Investing in children and youth

- Addressing the diverse needs and challenges faced by countries in special situations

- Global partnership

\section{UPCOMING EVENTS TO BE CONDUCTED} BY FfSD FORUM (Source: Upcoming events to be conducted by FfSD Forum during 2020, FSD, UNDESA, New York)

The following upcoming events are planned to be conducted during 2020 by FfSD Forum, UNDESA, but may be postponed/rescheduled at future dates due to COVID-19 pandemic:

1. 2020 ECOSOC Forum on Financing for Development Follow-up 20-23 April 2020 at New York, United States

2. Twentieth Session of the Committee of Experts in International Cooperation Matters 27-30 April 2020 New York, United States

3. ECOSOC Special Meeting on International Cooperation in Tax Matters 1 May 2020, New York, United States
4. 2020 Development Cooperation Forum High Level Meeting 14-15 May 2020, New York, United States

5. Twenty first Session of the Committee of Experts on International Cooperation in Tax Matters 20-23 October 2020, Geneva, Switzerland

\section{GLOBAL ISSUES FOR FFSD FORUM (FSDR 2019 ODA Update Financing for Sustainable Development Report, UNDESA, New York, April 2019)}

The global issues encompassing the various countries addressed by FfSD Forum, UNDESA are:
i) Domestic Public Resources
ii) Private Business and Finance
iii) Development Cooperation
iv) Trade, Debt, Systemic
v) Technology and Capacity
vi) Global Economic Governance
vii) External Debt
viii) Innovation Finance
ix) Inclusive and Local Finance
x) Tax Cooperation

\section{Stakeholders Work streams}

The Addis Ababa Action Agenda, adopted at the 2015 Third International Conference on Financing for Development, calls for the engagement of local authorities, civil society, academia and the private sector to achieve effective follow-up to the financing for development outcomes and all the means of implementation of the 2030 Agenda for Sustainable Development (Para 130).

In line with this mandate and responding to the demand and interest from various stakeholders, the Financing for Development Office(FSDO) has launched "Stakeholder work streams" that focus on selected issues from the Addis Agenda and will provide substantive input to the ECOSOC forum on Financing for Development follow-up viz;

- Work stream on "Strengthening Municipal Finance in LDCs" has been launched in close collaboration with UNCDF and local authorities.

- Work stream on "Exploring Public-Private Interfaces" has been initiated by the CSO FfD Group.

- Work stream on "SDG Investing (SDGI)" has been initiated by the Division for Sustainable Development (DSD) in collaboration with a wide range of business sector representatives.

The stakeholder work streams build on the rich programme of multi-stakeholder consultations carried out in follow-up to the Monterrey and Doha Conferences. 


\section{TAX COOPERATION}

International tax cooperation for development has featured prominently on the United Nations development agenda, as contained in the outcomes of major United Nations conferences and summits in economic and social fields.

A subsidiary body of ECOSOC, tasked with work on international tax cooperation, is the 25-member Committee of Experts on International Cooperation in Tax Matters (the Committee). Its core mandate is to keep under review and update as necessary the UN Model Double Taxation Convention between Developed and Developing Countries and the Manual for the Negotiation of Bilateral Tax Treaties between Developed and Developing Countries. In addition, the Committee provides a framework for dialogue with a view to enhancing and promoting cooperation among national tax authorities; considers how new and emerging issues could affect international tax cooperation and develops assessments, commentaries and appropriate recommendations; and makes recommendations on capacity-building and the provision of technical assistance. In all its activities, the Committee gives special attention to developing countries.

\section{GLOBAL ECONOMIC GOVERNANCE}

An enabling international environment is fundamental to the mobilization and effective use of financing for sustainable development. In the Monterrey Consensus on Financing for Development, Member States recognized the urgent need to enhance coherence, governance, and consistency of the international monetary, financial and trading systems. In this regard, the Consensus underlined the importance of continuing to improve global economic governance and to strengthen the United Nations leadership role in promoting development.

The adoption of the 2030 Agenda for Sustainable Development, the AAAA and the Paris Agreement marks a major step forward in enhancing the role of the United Nations in global economic governance and sustainable development. These global agreements, representing the shared commitment at the highest political level, established the ultimate objectives and overarching global frameworks for implementation of the Sustainable Development Goals.

\section{EXTERNAL DEBT}

External debt is one of the key chapters of the 'Monterrey Consensus' and 'Doha Declaration' on Financing for Development. Since 2002, it has been at the core of the FfD follow-up process, including through the work of the General Assembly and Economic and Social Council (ECOSOC). "External debt sustainability and development" is one of the selected topics from the FfD agenda examined by the Second Committee of the General Assembly under the item entitled "Macroeconomic policy questions." The issue has also been central to 'Millennium Development Goal 8'.
The Financing for Development Office has been organizing multi-stakeholder consultations on external debt, with the participation of all relevant stakeholder groups (governments, international organizations, private sector and civil society) to identify issues in sovereign debt restructuring that need policy action to make crisis prevention and management more effective and ensure debt sustainability and orderly functioning of financial markets. The aim is to identify incremental steps that stakeholders can agree on and implement in improving the functioning of the international financial system for debt restructuring and follow-up on the commitment to policy actions on debt in the Monterrey Consensus and the Doha Declaration on Financing for Development.

\section{INNOVATIVE FINANCING FOR DEVELOPMENT}

Achieving the Millennium Development Goals and addressing global challenges such as climate change require considerable financing. Finding the necessary resources is challenging, especially for least developed countries. Official development assistance (ODA) is falling short of what countries need, and ODA commitments remain unfulfilled.

The need for additional and more predictable development financing has led to a search for alternative, innovative sources. The Monterrey Consensus recognized "the value of exploring innovative sources of finance provided that those sources do not unduly burden developing countries", and encouraged "exploring innovative mechanisms to comprehensively address debt problems of developing countries, including middle-income countries and countries with economies in transition.”

Inclusive and Local Finance

\section{Inclusive finance}

Financial inclusion is universal access, at a reasonable cost, to a wide range of financial services, provided by a variety of sound and sustainable institutions. Inclusive finance strives to enhance access to financial services for both individuals and micro, small and medium-sized enterprises. In developing countries, access to financial services is crucial to strengthen financial sectors and domestic resource mobilization and can therefore make a significant contribution to social and economic development.

\section{Local finance}

The Addis Ababa Action Agenda (AAAA), adopted at the Third International Conference on Financing for Development (Addis Ababa, 13-16 July 2015), recognizes that "expenditures and investments in sustainable development are being devolved to the sub-national level, which often lack adequate technical and technological capacity, financing and support” (Para 34) and calls for greater international cooperation "to strengthen capacities of municipalities and other local authorities". The commitment in the AAAA to strengthen subnational finance is particularly relevant in the context of Goal 11 of the 2030 Sustainable Development Agenda which sets 
out to "make cities and human settlements inclusive, safe, resilient and sustainable".

The Financing for Development Office (FSDO) works closely with UNCDF to promote international cooperation on municipal finance through knowledge sharing among stakeholders in local sustainable development and subnational finance.

\section{GLOBAL INVESTORS FOR SUSTAINABLE DEVELOPMENT ALLIANCE (GISDA)}

The magnitude of financing required to implement the 2030 Agenda for Sustainable Development is significant, yet to date, levels of investment have been insufficient. While public resources will be essential, the mobilization of the private sector is critical to the implementation of the Sustainable Development Goals.

To help address this shortfall, the Secretary-General, UN has convened the Global Investors for Sustainable Development (GISD) Alliance as part of his Strategy for Financing the 2030 Agenda for Sustainable Development. The group is aimed at leveraging the insights of private sector leaders to remove impediments and implement solutions for mobilizing resources for sustainable development.

The Alliance has a two-year timeline, from October 2019 to October 2021. It will focus on facilitating solutions relating to:

- increasing the available supply of long-term investment for sustainable development;

- realizing SDG investment opportunities in developing countries;

- enhancing the impact of private investment on sustainable development.

Goals of GISD (Global Investors for Sustainable Development)

GISD (Global Investors for Sustainable Development) will aim to achieve the following:

- Generate support and adoption of actions required to mobilize long-term finance and investment for sustainable development.

- Encourage measures to channel finance and investment to countries and sectors where they are most needed.

- Work towards enhancing the impact of private investment on sustainable development.

- Facilitate the alignment of business operations, finance and investment with the 2030 Agenda for Sustainable Development.
KEY MESSAGES CONVEYED BY UN UNDER SECRETARY GENERAL IN THE FINANCING FOR SUSTAINABLE DEVELOPMENT REPORT (FSDR 2019) PUBLISHED BY UNITED NATIONS VIZ

1) While global growth is steady, it has peaked; debt risks are rising; and climate change continues apace. These global challenges put our aspirations at risk and raise the urgency of action.

2) In this difficulty lies opportunity. The multilateral system is under strain, but as we revisit existing arrangements in trade, debt, tax cooperation and other areas, we open the door to making them fit for purpose for sustainable development.

3) Rather than retreating from multilateralism, the international community must recommit to the Addis Ababa Action Agenda (AAAA) and strengthen collective action to address global challenges.

4) Global approaches need to be complemented by national actions. Countries should consider developing integrated national financing frameworks to support national development strategies.

5) Achieving sustainable development requires a longterm perspective. Public and private incentives need to be aligned with sustainable development so that all financing decisions incorporate sustainability as a central concern.

6) We must harness the potential of innovation to strengthen development finance. Yet such innovations do not eliminate financial and sustainability risks, which policy makers and regulators need to manage carefully.

\section{FINANCING FOR SUSTAINABLE DEVELOPMENT: GLOBAL ODA DATA UPDATE (Source: FSDR 2019, UN)}

Global ODA, and aid for least developed countries, falls 2.7 per cent in 2018.

- ODA fell 2.7 per cent in 2018 in real terms, based on a comparable basis from 2017.

- The fall reflects a decline in aid spent on hosting refugees net of this spending, ODA remained stable.

- Net bilateral aid from DAC donors to LDCs declined by 2.7 per cent and aid to Africa dropped by 4 per cent.

- Reflecting a new reporting standard, the ODA of DAC donors as a share of their GNI stood at 0.31 per cent on average. 


\section{GLOBAL ASPIRATIONS AT RISK}

The world is being changed by rapid shifts in geopolitics, technology, climate, among other factors. There are some encouraging signs. Extreme poverty continues to decline and inequality among countries has fallen. Investment in some countries and regions has strengthened after a period of slow growth. Carbon prices are slowly recovering and there is growing interest in sustainable investing.

Nonetheless, many of the risks highlighted earlier have begun to materialize or intensify, putting progress at risk and raising the urgency of action, including in relation to the following:

(a) World economic growth remains steady at around 3 per cent, but has likely peaked;

(b) More than half a trillion dollars' worth of goods are subject to trade restrictions i.e. seven times more than in the previous reporting period;

(c) Debt risks are rising: a number of countries, including around 30 least developed and other vulnerable countries, are either already in or at high risk of debt distress, hampering their ability to invest in the Sustainable Development Goals;

(d) Several countries have experienced significant capital outflows, with aggregate net outflows of over $\$ 200$ billion from developing countries expected for 2018;

i. Inequality has risen in countries home to most people in the world, and global growth in real wages is only 1.8 per cent, the lowest since 2008;

ii. Climate change continues apace, with greenhouse gas emissions having increased by 1.3 per cent in 2017, with dire consequences for communities worldwide.

Achieving sustainable development requires multilateral action to address global challenges; revisiting the global institutional architecture; and strengthened regional and national action, including adjusting policies to the changing global landscape. It includes countering short-term behavior on all levels and harnessing the potential of innovation while managing risks.

\section{ADOPT INTEGRATED NATIONAL FINANCING FRAMEWORKS AND ADJUST POLICIES TO NEW REALITIES}

(i) In the Addis Ababa Action Agenda, it was noted that cohesive nationally owned sustainable development strategies, supported by integrated national financing frameworks, would be at the heart of efforts. In response to the 2030 Agenda, many countries have injected new life into their sustainable development strategies. However, most strategies do not have concrete financing plans to fund their implementation.

(ii) The Task Force has identified four building blocks for operationalizing integrated national financing frameworks. All countries should consider developing financing frameworks to support their national development strategies. The international system should continue to support countries in these endeavors.

(iii) Financing policies do not work in isolation. Integrated financing frameworks should not only respond to financing challenges, but also to the realities of a changing global landscape. For example, to combat inequality, including gender inequalities, national policies will need to address the falling wage share, growing vulnerabilities, digitization and increasing market concentration, among other issues. Governments should revisit their labor market policies, social protection systems, fiscal policies, competition policies, trade policies and financial sector regulations and strategies to ensure that they are in line with the new realities.

INTER-AGENCY TASK FORCE ON THE FOLLOW-UP TO THE FINANCING FOR DEVELOPMENT OUTCOMES AND THE MEANS OF IMPLEMENTATION OF THE 2030 AGENDA FOR SUSTAINABLE DEVELOPMENT (IATF ON FfD) (Source: Terms of Reference of IATF (Inter Agency Task Force) on the follow-up to the Financing for Development Outcomes and the Means of Implementation of the 2030 Agenda for Sustainable Development, 2019, United Nations, New York)

The Addis Ababa Action Agenda provides a new global framework for financing sustainable development, which supports implementation of the 2030 Agenda for Sustainable Development, including the Sustainable Development Goals (SDGs). The Addis Agenda aligns all domestic and international resource flows, policies and international agreements with economic, social and environmental priorities. It incorporates all the SDG means of implementation (MoI) targets into a comprehensive financing framework. It also serves as a guide for further actions by governments, international organizations, the business sector, civil society, and philanthropists.

Successful implementation of the Addis Agenda will rely on engagement by all relevant stakeholders in a vibrant and revitalized global partnership. Mechanisms for monitoring, follow-up and review will be essential in this regard. In the Addis Agenda, countries commit to staying engaged through a dedicated and strengthened follow-up process.

In this context, the Addis Agenda establishes an annual ECOSOC Forum on Financing for Development follow-up (FfDF) with universal intergovernmental participation to review the implementation of financing for development outcomes and the means of implementation of the 2030 
Agenda. Its intergovernmental agreed conclusions and recommendations will feed into the High-level Political Forum on Sustainable Development (HLPF). The deliberations of the Development Cooperation Forum, according to its mandate, will also be taken into account.

\section{Mandate}

The mandate for the IATF emanates from paragraph 133 of the Addis Agenda which reads as:

Paragraph 133: To ensure a strengthened follow-up process at the global level, we encourage the SecretaryGeneral to convene an inter-agency task force, including the major institutional stakeholders and the United Nations system, including funds and programmes and specialized agencies whose mandates are related to the follow-up, building on the experience of the Millennium Development Goals Gap Task Force. The inter-agency task force will report annually on progress in implementing the financing for development outcomes and the means of implementation of the post-2015 development agenda and advise the intergovernmental follow-up thereto on progress, implementation gaps and recommendations for corrective action, while taking into consideration the national and regional dimensions.

1. In its resolution 73/220, the General Assembly recognized the need to continue to enhance the coherence and consistency of the international monetary, financial and trading systems, and to ensure their openness, fairness and inclusiveness. It also encouraged the international financial institutions to align their programmes and policies with the 2030 Agenda for Sustainable Development and stressed the critical importance of a stable global economic environment for the implementation of the 2030 Agenda.

2. The world is being reshaped by rapid shifts in geopolitics, globalization, geo-economics, technological advancement, the climate and other factors. Global systemic risks have been rising, raising doubts as to whether the multilateral financial and economic architecture is equipped to address current global challenges.

3. To implement the 2030 Agenda, the financial system needs to intermediate credit towards sustainable development in an inclusive and stable manner. Since the financial crisis of 2008, financial sector reforms have reduced important systemic risks, while access to financial services has increased in many countries, owing, in part, to the growth of financial technology. Yet, the implementation of the reforms is incomplete and new risks have emerged, including risks arising from the fact that financial technology operating outside traditional regulatory boundaries has grown. At the same time, the financial system fails, as before, to allocate adequate resources to meeting long-term sustainable development needs. In many areas critical to the Sustainable Development Goals, investment is insufficient.

4. In a period of political uncertainty, achieving the required transformation of the financial system will require domestic actions and strengthened international cooperation, both of which are necessary to ensure that adequate resources are available and that the financial safety nets designed to protect countries from instability provide comprehensive coverage. Ultimately, stability and sustainability are mutually reinforcing; longer-term investment in sustainable development can reduce short-term financial volatility, while the absence of a stable financial system makes it impossible to attain the Sustainable Development Goals.

\section{ECONOMIC AND FINANCIAL TRENDS AND ROLE OF MULTILATERAL FINANCIAL INSTITUTIONS ( Source: WESP Report 2019,} $U N)$

In its mid-year update of the World Economic Situation and Prospects for 2019, the Economic and Social Council forecasts that world gross product growth will be 2.7 per cent in 2019 and 2.9 per cent in 2020, a slight downgrade from yearend forecasts. Economic growth remains highly uneven across regions and countries. Per capita growth in Africa, Western Asia, and Latin America and the Caribbean is, on average, significantly below 1.5 per cent. Together those regions are home to half of the world's people living in extreme poverty.

Debt sustainability remains a concern. As of May 2019, of the 46 least developed countries covered by the Debt Sustainability Framework for Low-Income Countries of the World Bank and the International Monetary Fund (IMF), 5 were in debt distress, and 13 more were classified as being at high risk. In the period of low interest rates between 2007 and 2017 , the total external debt of the least developed countries more than doubled, jumping from $\$ 146$ billion to $\$ 313$ billion. Of that amount, around 60 per cent was concessional. In 2017, the debt service burden of the least developed countries as a group exceeded 6 per cent of exports (and in some individual cases exceeded 10 per cent), approaching levels last seen before the debt relief initiatives of the early 2000s. In a context of heightened uncertainty and persistent financial stability risks, the growing debt levels in least developed countries may undermine their ability to make sufficient investments to achieve the Sustainable Development Goals (SDGs).

The evolving global outlook is reflected in policy responses. In developed economies, central banks had been indicating for many years that they would gradually tighten monetary policy from the historic low interest rates set in the wake of the 2008 financial crisis. However, because of economic uncertainty and policy risks compounded by weakerthan-expected inflation and growth, they have placed that tighter monetary policy on hold. Monetary policy may even become looser in some cases; in the United States of America, early in 2019, the treasury yield curve inverted, meaning that longer-term bonds provided lower returns than very shortterm bonds. This indicates that investors were pricing in an easing of monetary policy.

The volatility that affected the exchange rates in a number of emerging markets in the first half of 2018 did not lead to a 
depreciation of developing countries' currencies. The rise in dispersion of currency volatility affecting emerging markets in 2018 to levels not seen since the financial crisis indicates that financial markets have been differentiating between countries, with capital outflows and pressures on exchange rates more acute in countries with weaker fundamentals or higher political risk. Nonetheless, IMF has assessed that mediumterm risks to broader financial stability remain elevated and that a prolonged period of "easy money" could result in a more severe downturn later.

Recent progress on gender equality has been marginal at best. Globally, the labour force participation rate of women, at 48 per cent in 2018 , was 27 percentage points below the rate for men. The gap between wages earned by women and men lies between 16 and 22 per cent, depending on the estimation technique. In developed countries, the gender pay gap is largest at the top of the income distribution scale, while in poorer countries the gap is largest at the low end.

\section{FUNDING THE FIGHT AGAINST COVID-19 IN THE WORLD'S POOREST COUNTRIES}

The United Nations Department of Global Communications (DGC) promotes global awareness and understanding of the work of the United Nations.

The United Nations is calling for solidarity and increased funding, as some of the world's most vulnerable countries scale up their efforts to combat the coronavirus pandemic.

"Now, the virus is arriving in countries already in the midst of humanitarian crises caused by conflicts, natural disasters and climate change," said United Nations Secretary-General António Guterres as he, launched a \$2 billion global humanitarian response plan to fund the fight against COVID19 in the world's poorest countries (Statement of UN Secretary General).

“These are places where people who have been forced to flee their homes because of bombs, violence or floods are living under plastic sheets in fields or crammed into refugee camps or informal settlements. They do not have homes in which to socially distance or self-isolate", he said (Statement of UN Secretary General).

\section{It is a Crucial Part of Winning this Fight}

Coordinated by the United Nations Office for the Coordination of Humanitarian Affairs (OCHA), this interagency plan brings together existing appeals from the World Health Organization and other UN partners, and identifies new needs as well.

\section{ECONOMIC DEVELOPMENT}

As per UN release on $30^{\text {th }}$ March 2020, the economic fallout from COVID-19 is likely to get much worse before it gets better for some six billion people living in developing economies, the UN said on $30^{\text {th }}$ March, 2020 in an appeal for a $\$ 2.5$ trillion rescue package to boost their resilience to further hardship.
According to new analysis from UNCTAD, the UN Trade and Development body, commodity-rich exporting countries will face a $\$ 2$ trillion to $\$ 3$ trillion drop in investment from overseas in the next two years.

An economic downturn in these emerging economies was already evident in the last quarter of 2019 before the new coronavirus outbreak emerged in central China in December 2019 said Richard Kozul Wright, UNCTAD Director of Globalization and Development Strategies (Statement of UNCTAD Director of Globalization and Development Strategies).

\section{Crisis Yet to Come}

"The health crisis is still to come in many developing countries," he told UN News. "Now, if that crisis comes as these countries have been significantly weakened by the economic shockwaves from the crisis. And that is a very vicious combination of an economic crisis and a health crisis. So we've got to find ways of strengthening the healthcare system and services in developing countries and building up resilience on that front very quickly" (Statement of UNCTAD Director of Globalization and Development Strategies).

Rich industrial nations have already announced a \$5 trillion global rescue package plan to provide an economic safety net to their businesses and workers.

This unprecedented measure should reduce the extent of their shock "physically, economically and psychologically" said Mr. Kozul Wright (Statement of UNCTAD Director of Globalization and Development Strategies).

It is also expected to create $\$ 1$ trillion to $\$ 2$ trillion of demand among the major G20 economies, boosting global manufacturing by two per cent, he writes in his latest report (Report of UNCTAD Director of Globalization and Development Strategies).

\section{Recession Looms}

"Even so, the world economy will go into recession this year with a predicted loss of global income in the trillions of dollars this will spell serious trouble for developing countries, with the likely exception of China and the possible exception of India”, Mr. Kozul Wright warned (Statement of UNCTAD Director of Globalization and Development Strategies).

UNCTAD believes that part of the problem for many developing countries is that informal workers form the backbone of their emerging economies, which amplifies their difficulties in responding to the crisis.

\section{Four-point Recovery Plan}

Faced with "a looming financial tsunami" this year i.e. 2020 , UNCTAD’s four-pronged strategy initially calls for a $\$ 1$ trillion investment injection for weaker economies.

This would come from so-called "special drawing rights" governed by the International Monetary Fund (IMF) which would need to "go considerably beyond" the 2009 allocation made in response to the global financial crisis, the agency's report explains (Report of UNCTAD).

The second measure is a debt freeze for distressed economies, involving an immediate standstill on sovereign debt payments, followed by significant debt relief. 
By way of example, UNCTAD cites how half of Germany's debt after World War Two, was cancelled.

Based on this precedent, around $\$ 1$ trillion in debt should be cancelled this year, overseen by an independently created body, the UN agency maintains.

The third measure targets $\$ 500$ billion investment in poorer countries' emergency health services and related social relief programmes.

Finally, UNCTAD urges the implementation of State-led capital controls to curtail already surging capital outflows from these developing countries.

This would help to reduce a cash shortage driven by selloffs in developing country markets and to arrest declines in currency values and asset prices.

\section{UNCTAD PACKAGE EQUALS UNPAID INVESTMENT PLEDGES}

The proposed package is similar in size to the amount that would have been delivered to developing countries over the last decade if countries in the Development Assistance Committee of the Organization for Economic Co-operation and Development had met their 0.7 per cent Official Development Assistance target.

"Advanced economies have promised to do 'whatever it takes' to stop their firms and households from taking a heavy loss of income," said Mr. Kozul Wright. "But if G20 leaders are to stick to their commitment of 'a global response in the spirit of solidarity,' there must be commensurate action for the six billion people living outside the core G20 economies" (Statement of UNCTAD Director of Globalization and Development Strategies).

\section{THE RECOVERY FROM THE COVID-19 CRISIS MUST LEAD TO A DIFFERENT ECONOMY}

As per UN Secretary General statement made on $31^{\text {st }}$ March, 2020, the world is facing an unprecedented test. And this is the moment of truth.

Hundreds of thousands of people are falling seriously ill from COVID-19, and the disease is spreading exponentially in many places.

Societies are in turmoil and economies are in a nose-dive.

The International Monetary Fund has reassessed the prospect for growth for 2020 and 2021, declaring that the global economy have entered a recession as bad as or worse than in 2009.

We must respond decisively, innovatively and together to suppress the spread of the virus and address the socioeconomic devastation that COVID-19 is causing in all regions.

The magnitude of the response must match the scale of the crisis large-scale, coordinated and comprehensive, with country and international responses being guided by the World Health Organization.
And it must be multilateral, with countries showing solidarity to the most vulnerable communities and nations.

The message of the report we are issuing today is clear: shared responsibility and global solidarity in response to the impacts of COVID-19.

It is a call to action.

We must see countries not only united to beat the virus but also to tackle its profound consequences.

First, for an immediate coordinated health response to suppress transmission and end the pandemic.

A response that scales up health capacity for testing, tracing, quarantine and treatment, while keeping first responders safe, combined with measures to restrict movement and contact.

A response that delivers universal access to treatment and vaccines, when they are ready.

It is essential that developed countries immediately assist those less developed to bolster their health systems and their response capacity to stop transmission.

Otherwise, we face the nightmare of the disease spreading like wildfire in the global South with millions of deaths and the prospect of the disease re-emerging where it was previously suppressed.

Let us remember that we are only as strong as the weakest health system in our interconnected world.

The cause of worry and concern is with regards to the African continent, and UN Secretary General strongly encourage the G20 to move ahead with a G20 Africa initiative as proposed at the Summit.

Second, we must tackle the devastating social and economic dimensions of this crisis, with a focus on the most affected: women, older persons, youth, low-wage workers, small and medium enterprises, the informal sector and vulnerable groups, especially those in humanitarian and conflict settings.

We must see countries not only united to beat the virus but also to tackle its profound consequences.

That means designing fiscal and monetary policies able to support the direct provision of resources to support workers and households, the provision of health and unemployment insurance, scaled up social protection, and support to businesses to prevent bankruptcies and massive job losses.

What is needed is a large-scale, coordinated and comprehensive multilateral response amounting to at least 10 per cent of global GDP.

Developed countries can do it by themselves, and some are indeed doing so.

But we must massively increase the resources available to the developing world by expanding the capacity of the International Monetary Fund, namely through the issuance of special drawing rights, and the other international financial institutions to rapidly inject resources into the countries that need them.

Coordinated swaps among central banks can also bring liquidity to emerging economies. 
Debt alleviation must be a priority including immediate waivers on interest payments for 2020 .

The United Nations system is fully mobilized, providing guidance for global efforts, supporting country responses and placing our supply chains at the world's disposal.

And to support our efforts, the United Nations is establishing a new multi-partner Trust Fund for COVID19 Response and Recovery to support low and middle-income countries to respond to the emergency and recover from the socio-economic shock.

UN Resident Coordinators worldwide will be the drivers of the UN response on the ground, ensuring that the wide and diverse expertise and assets of the United Nations system are used in the most efficient and effective way to support countries.

Finally, when we get past this crisis which we will, we will face a choice.

We can go back to the world as it was before or deal decisively with those issues that make us all unnecessarily vulnerable to crises.

Our roadmap is the 2030 Agenda and the 17 Sustainable Development Goals.

The recovery from the COVID-19 crisis must lead to a different economy.

Everything we do during and after this crisis must be with a strong focus on building more equal, inclusive and sustainable economies and societies that are more resilient in the face of pandemics, climate change, and the many other global challenges we face.

What the world needs now is solidarity.

With solidarity we can defeat the virus and build a better world.

(Statement of UN Secretary-General on recovery from the COVID-19 crisis)

\section{Social, Economic, Multi-dimensional Aspects and Impacts of COVID-19}

The world is facing a global health crisis unlike any in the 75-year history of the United Nations one that is killing people, spreading human suffering, and upending people's lives. But this is much more than a health crisis. It is a human crisis. The coronavirus disease (COVID-19) is attacking societies at their core.

The IMF has just reassessed the prospect for growth for 2020 and 2021, declaring that the world has entered a recession as bad as or worse than in 2009. The IMF projects recovery in 2021 only if the world succeeds in containing the virus and takes the necessary economic measures. In the face of such an unprecedented situation in recent history the creativity of the response must match the unique nature of the crisis and the magnitude of the response must match its scale. No country will be able to exit this crisis alone.

The report of United Nations on 'Shared Responsibility and Global Solidarity Responding to the Socio-Economic Impacts of COVID-19' March 2020' (UN Publication 2020) is a call to action, for the immediate health response required to suppress transmission of the virus to end the pandemic and to tackle the many social and economic dimensions of this crisis. It is, above all, a call to focus on people, women, youth, lowwage workers, small and medium enterprises, the informal sector and on vulnerable groups who are already at risk.

A large-scale coordinated, comprehensive and multilateral response amounting to at least 10 percent of global GDP is needed now more than ever. It is in everyone's interest to ensure that the developing countries have the best chance of managing this crisis or COVID-19 will risk becoming a longlasting brake on economic recovery.

The United Nations family and the global network of regional, sub-regional and country offices of UN working for peace, human rights, sustainable development and humanitarian action will support all governments working with UN partners to ensure first and foremost that lives are saved, livelihoods are restored and that the global economy and the people we serve emerge stronger from this crisis. The 'Decade of Action to deliver the SDGs' advocates such logic. For than this, solidarity, hope, political will and cooperation is required to see this crisis through together.

The third step is to learn from this crisis and build back better. Had we been further advanced in meeting the Sustainable Development Goals(SDGs) and the Paris Agreement on Climate Change, we could better face this challenge with stronger health systems, fewer people living in extreme poverty, less gender inequality, a healthier natural environment and more resilient societies. We must seize the opportunity of this crisis to strengthen our commitment to implement the 2030 Agenda and the 17 Sustainable Development Goals. By making progress on our global roadmap for a more inclusive and sustainable future, we must respond to future crises (Report of United Nations March 2020).

Decisive, urgent and coordinated action by all leaders of nations, businesses, finance, science and communities is needed to suppress transmission of the virus as quickly as possible and stop the pandemic.

\section{Urgently Strengthen the Resilience of Health Systems}

\section{Provide urgent support to developing countries with weaker health systems}

The most vulnerable in the face of this crisis are those who are already at risk, those caught up in or fleeing war and persecution, those already living in highly concentrated and under-served areas, those whose lives have already been upended for other reasons and who lack access to basic social and political protections or to any support systems. Countries with large populations and significant informal sectors are especially vulnerable. The risk for the disease to take a deep foothold in fragile contexts and in poor and densely populated urban areas and slums, unable to self-isolate, would leave us all at risk as the virus continues to spread across the globe.

Countries need to work together to develop a sciencebased, cooperative approach to allocating scarcer resources on the basis of a truly collective public health needs assessment. Otherwise, key resources will languish unused where they are not needed, and not be available at critical moments where and when they are. This puts us all at risk. The UN is ready to convene and support all efforts. 
The Effects on People and the Formal and Informal Economy are Devastating

COVID-19 is hitting hard an already weak and fragile world economy. Global growth in 2019 was already the slowest since the global financial crisis of 2008/2009. COVID-19 has plunged the world economy into a recession with potential of deep consequences and historical levels of unemployment and deprivation. Necessary measures to contain the spread of the disease through quarantines, travel restrictions and lockdown of cities have resulted in significant reduction in demand and supply. Economic activities in transportation, retail trade, leisure, hospitality and recreation have been battered. And we have seen from plunging stock markets that public trust in the health response has direct and immediate economic effects.

The supply chain disruptions halting the manufacturing industry and the falling commodity prices, in particular oil, further compound the economic impact of the pandemic. This has rattled the financial markets, tightened the financial markets liquidity conditions in many countries, created unprecedented outflows of capital from developing countries and put pressure on the foreign exchange markets, with some countries experiencing dollar shortages. Weak local currencies will constrain the government's ability for fiscal stimulus at the scale needed to stabilize the economy and to tackle the health crisis and human crisis. The situation in developing countries, LDCs, LLDCs and SIDS in particular, is of special concern. The spreading of the virus to these countries will further weaken an already fragile macroeconomic picture, where debt accumulation has outpaced the growth of income even before the crisis. In addition, in some of these countries, the required hygiene and sanitation standards and social distancing measures are hard to implement.

\section{IMPLICATIONS FOR THE 2030 AGENDA AND THE PARIS AGREEMENT}

The COVID-19 crisis is likely to have a profound and negative effect on sustainable development efforts. A prolonged global economic slowdown will adversely impact the implementation of the 2030 Agenda for Sustainable Development and the Paris Agreement on Climate Change.

\section{POLITICAL LEADERSHIP AND COOPERATION TO COMBAT COVID-19}

At the geopolitical level, this crisis cries out for leadership, solidarity, transparency, trust and cooperation. This is no time for self-interest, recrimination, censorship, obfuscation or politicization. The tone set by leaders at the national and local level matters. While temporary border closures, travel bans or limits on the sale of critical supplies may be warranted in the short-term, such national-level measures must not impede a global coming together and global solution for all.

\section{PARTNERSHIPS TO ACCELERATE THE GLOBAL RESPONSE TO COVID-19}

\section{Local and National Authorities}

Local governments are at the frontline of the pandemic. The capacity of local governments to respond rapidly with the needed health and socioeconomic measures depends heavily on the governance context of the country and the financial health of the local government and its budgetary authority. Effective dialogue and coordination between local and national authorities are critical for implementing effective measures. Women and youth will be key to these dialogues at local levels.

\section{GLOBAL RESEARCH AND INNOVATION}

This is as much a crisis of confidence occasioning a risk of panic and irrational behavior as it is a public health crisis. Evidence based innovation will illuminate the path out of this crisis and that requires rapid action by researchers and innovators worldwide.

Medical and technological research and innovation is needed to accelerate the production of key medical materials and tests and to discover the vacancies and therapeutic treatments that are needed to protect people's right to health.

\section{CALL TO ACTION}

The COVID-19 pandemic is a defining moment for modern society and history will judge the efficacy of our responsibility by the actions of any single set of government actors taken in isolation, but by the degree to which the response is coordinated globally across all sectors to the benefit of our human family.

The United Nations global footprint at the national level is an asset for the global community to be leveraged to deliver the ambition needed to win the war against the virus.

With the right actions, the COVID-19 pandemic can mark the rebirthing of society as we know it today to one where we protect present and future generations. It is the greatest test that we have faced since the formation of the United Nations, one that requires all actors i.e. governments, academia, businesses, employers and workers' organizations, civil society organizations, communities and individuals to act in solidarity in new, creative, and deliberate ways for the common good and based on the core United Nations values that we uphold for humanity.

\section{ECONOMIC DEVELOPMENT}

As governments struggle to cope with the COVID-19 pandemic, billions of people living in countries teetering on the brink of economic collapse are being threatened further by a looming debt crisis, according to a new $\mathbf{U N}$ report released on $9^{\text {th }}$ April, 2020. 
In its report, the 'UN-led Inter-Agency Task Force on Financing for Development' explores the steps that governments must take to avert debt overload and address the economic and financial havoc wrought by the pandemic.

COVID-19 is causing investors to flee to safety, leading to equity volatility, widening bond spreads and depreciating currencies setting the stage for debt and financial crises, says Shari Spiegel, Chief of Policy and Development Branch, Financing for Sustainable Development Office, UNDESA, New York (Statement of Chief of Policy and Development Branch, FfSD Office, UNDESA).

The global community was already falling behind in efforts to end poverty, take climate action and reduce inequalities", said UN Deputy Secretary-General Amina Mohammed. "We have one chance to build back better together for people and for the planet" (Statement of UN Deputy SecretaryGeneral).

With recommendations based on joint research and analysis from more than $60 \mathrm{UN}$ agencies and international institutions, the 2020 Financing for Sustainable Development Report outlines measures to address the impact of the unfolding global recession and financial turmoil particularly in the world's poorest countries.

\section{LEAST DEVELOPED COUNTRIES}

The COVID-19 crisis has shaken global financial markets with heavy losses and intense volatility that has prompted investors to move around $\$ 90$ billion out of emerging markets the largest outflow ever recorded.

Particularly alarming for many Least Developed Countries (LDCs) is the prospect of a new debt crisis.

To mitigate this, 2020 Financing for Sustainable Development calls, among other things, suspending debt payments from LDCs and other low-income countries; strengthening the global financial safety net; and reversing the decline in official development assistance.

"We are far from having a global package to help the developing world to create the conditions both to suppress the disease and to address the dramatic consequences in their populations”, said UN Secretary-General, António Guterres, during the recent launch of his Report on the Socioeconomic Impact of COVID-19 (Statement of UN Secretary General).

"What is needed is a large-scale, coordinated and comprehensive multilateral response amounting to at least 10 per cent of global GDP", he added (Statement of UN Secretary General).

\section{Long-overdue Measures}

Beyond the immediate crisis response, the coronavirus pandemic should prompt the implementation of long-overdue measures to reset the world on a sustainable development path and make the global economy more resilient to future shocks.

To do this, the report recommends accelerating investment in resilient infrastructure, strengthening social protections, enhancing regulatory frameworks, and strengthen the international financial safety net and framework for debt sustainability.
While highlighting gaps, new challenges and risks, the current crisis also provides a timely example of the potential of digital technologies.

As lockdowns and physical distancing have become the norm, digital communication tools have helped keep people connected and provided online platforms for children to continue their education.

But many workers in the so-called "gig economy", dominated by service sector start-ups, are poorly protected against income losses in a recession. 2020 Financing for Sustainable Development addresses these gaps and other opportunities and challenges of digital finance.

"Only a collective response, inspired by shared responsibility and solidarity, will suffice to address the unprecedented challenges of the COVID-19 pandemic", said Liu Zhenmin, Under-Secretary-General for Economic and Social Affairs and Chair of the Task Force that issued the report (Statement of Under Secretary General, Economic and Social Affairs, UN).

"Governments, development partners, the private sector and other stakeholders must work together to combat COVID19 and support every effort to address its social and economic impacts," he underscored (Statement of Under Secretary General, Economic and Social Affairs, UN).

\section{EXCERPTS FROM FINANCING FOR SUSTAINABLE DEVELOPMENT REPORT 2020 (Source: FSDR 2020, UN)}

The global economic recession and financial turmoil from COVID-19 are derailing implementation of the Addis Ababa Action Agenda (AAAA) and achievement of the Sustainable Development Goals (SDGs). Even before the pandemic, the 2020 Financing for Sustainable Development Report (FSDR) of the Inter-agency Task Force noted that there was backsliding in many areas. Due to the COVID-19 crisis, global financial markets have witnessed heavy losses and intense volatility. Particularly worrisome is the prospect of a new debt crisis. The FSDR highlights both immediate and longer-term actions, including arresting the backslide, to respond to the COVID-19 crisis. The FSDR 2020 calls for:

- A globally coordinated stimulus package, including reversing the decline in aid and increased concessional finance.

- To prevent a debt crisis.

- Immediately suspending debt payments from poor countries.

- Beyond the crisis, reassess debt sustainability/revisit existing mechanisms.

- To stabilize financial markets by continuing to inject liquidity:

- In the medium-term, explore regulatory frameworks to limit over-borrowing for non-productive investments, such as repaying shareholders.

- Partnering with the private sector: 
- In the short term, banks to roll over debt to SMEs and individuals that are cash strapped.

- In the medium-term, promote sustainable investment.

- Building back better for sustainable development:

- Public and private investment in sustainable development including in resilient infrastructure.

- Strengthening social protection systems.

- Investment in crisis prevention, risk reduction and planning.

- Eliminate trade barriers and restrictions that affect supply chains.

- Digital technologies present tremendous potential for the SDGs, but COVID-19 has underlined challenges and risks.

- Public policies should be adjusted to fully exploit their potential, while addressing exclusion and risks of discrimination, and ensuring benefits for society at large, including decent jobs.

The 2020 FSDR begins with an analysis of the extremely challenging global macroeconomic context. The report analyses financing sustainable development in an era of transformative digital technologies. The report discusses progress in the seven action areas of the Addis Agenda, and presents policy options at the national and international level.

The 2020 FSDR is the fifth report on implementing the Financing for Development outcomes and the means of implementation of the SDGs since the adoption of the 2030 Agenda and the Addis Ababa Action Agenda. The assessment draws on the expertise, analysis and data from more than 60 agencies and international institutions that make up the Task Force, which is led by UN DESA and includes the World Bank Group, the International Monetary Fund and the World Trade Organization, UNCTAD and UNDP in leading roles.

The global economic recession and financial turmoil from COVID-19 are derailing implementation of the Addis Ababa Action Agenda and achievement of the Sustainable Development Goals (SDGs). Even before the global pandemic, the 2020 Financing for Sustainable Development Report (FSDR) of the Inter-agency Task Force noted that there was backsliding in many areas. Due to the COVID-19 crisis, global financial markets have witnessed heavy losses and intense volatility. Particularly worrisome is the prospect of a new debt crisis.

\section{PRESS RELEASE ON COVID-19 APRIL 9, 2020 UNDESA (Source: FSDR 2020 Press Release, April 9, 2020, United Nations, New York)}

Governments must take immediate steps to prevent a potentially devastating debt crisis and address the economic and financial havoc wrought by the COVID-19 pandemic says a report from the United Nations-led Inter-Agency Task Force on Financing for Development.
The UN System's 2020 Financing for Sustainable Development Report outlines measures to address the impact of the unfolding global recession and financial turmoil, especially in the world's poorest countries. Its recommendations are based on joint research and analysis from the UN System, the International Monetary Fund, World Bank Group, and more than $60 \mathrm{UN}$ agencies and international institutions.

Even before the outbreak of COVID-19, one in five countries home to billions of people living in poverty were likely to see per capita incomes stagnate or decline in 2020. Now, billions more are likely to be affected as governments struggle to cope with the pandemic.

"The global community was already falling behind in efforts to end poverty, take climate action and reduce inequalities," said Deputy Secretary-General of the United Nations Amina Mohammed.(Statement of Deputy Secretary General, United Nations) "COVID-19 is the first of its kind development emergency and all countries must rise to the challenge to save lives and safeguard livelihoods in our response and recovery. We have one chance to build back better together for people and for the planet."

Due to the COVID-19 crisis, global financial markets have witnessed heavy losses and intense volatility over the last month. Investors have moved around $\$ 90$ billion out of emerging markets the largest outflow ever recorded.

Particularly alarming is the prospect of a new debt crisis, compounded by tumbling prices for oil and other key commodities. Many Least Developed Countries (LDCs) were already at high risk of debt distress and the fall-out from the current crisis could significantly increase the number.

The 2020 Financing for Sustainable Development Report calls for the following urgent actions:

- Prevent a debt crisis by immediately suspending debt payments from LDCs and other low-income countries that request forbearance. Official bilateral creditors must lead, and others should consider similar or equivalent steps to provide new finance;

- Reestablish financial stability by providing sufficient liquidity, and strengthening the global financial safety net, especially for emerging markets;

- Contain the sharp fall in economic activity and support countries most in need through a globally coordinated response: expanding public health spending; social protection; keeping small businesses afloat; government transfers; debt forbearance and other national measures and significantly increasing access to concessional international financing.

- Promote trade and stimulate inclusive growth by eliminating trade barriers that restrict supply chains.

Despite enormous domestic pressures, donors should immediately reverse the decline in official development assistance (ODA), particularly to LDCs, who may be hard hit by both social and economic impacts of COVID-19, and for whom ODA remains essential. In 2018, ODA declined by 4.3 per cent and ODA to LDCs fell by 2.2 per cent in real terms. 
"We are far from having a global package to help the developing world to create the conditions both to suppress the disease and to address the dramatic consequences in their populations," said UN Secretary-General, António Guterres, during the recent launch of his Report on the Socioeconomic Impact of COVID-19 (Statement of UN Secretary General).

"What is needed is a large-scale, coordinated and comprehensive multilateral response amounting to at least 10 per cent of global GDP," he added (Statement of UN Secretary General).

Beyond the immediate crisis response, the COVID-19 pandemic should be the impetus to sustain the gains and accelerate implementation of long-overdue measures to set the world on a more sustainable development path and make the global economy more resilient to future shocks.

- The 2020 Financing for Sustainable Development Report contains key actions needed for this purpose:

- accelerate long-term investment in resilient infrastructure for sustainable development, through public investment and incentives for the private sector;

- increase investment in risk management and preparedness;

- strengthen social protection;

- enhance regulatory frameworks, e.g. to discourage excessive private borrowing when debt is not intended for productive investments (vs. increasing shareholder returns);

- strengthen the international financial safety net and framework for debt sustainability.

The report also provides policy options to harness the potential of digital technologies. These technologies have come to the forefront amid the COVID-19 outbreak, with lockdowns and physical distancing becoming the norm. Digital communication tools have also helped sustain interaction and continuity in vital economic and educational activities. However, access to digital technologies remains highly unequal within and between countries. Almost half the global population (46.4 per cent of people) does not have access to the Internet.

The COVID-19 crisis provides a timely example of the potential of digital technologies, but also highlights gaps and new challenges and risks. Many workers in the platform or 'gig economy' are poorly protected against massive income losses in a recession, with social protection systems often illequipped to address their needs. The report addresses these gaps and other opportunities and challenges of digital finance.

These and other policy responses should be sustained, sustainable and equitable, to avoid a rerun of the protracted and slow recovery from the 2008 crisis and ensure implementation of the Addis Ababa Action Agenda, Paris Agreement and achievement of the Sustainable Development Goals.

\section{POLICY BRIEF OF UNDESA ON COVID-19}

\section{APRIL 2020 (Source: Policy Brief No.59, COVID-19, UNDESA, New York)}

The policy brief of UNDESA analyses the impact of COVID19 on financial sector and puts forward policy recommendations, focusing on how the international community can support countries most in need in four areas viz ; (i) launching a large-scale coordinated stimulus package that includes a significant increase in access to concessional financing, (ii) strengthening the global financial safety net, (iii) initiating a debt moratorium and (iv) in the medium-term building a more sustainable future. These measures should complement other national and international actions to address the health, social and economic impact of the crisis.

\section{POLICY IMPLICATIONS AND CONCLUDING OBSERVATIONS}

The research paper entitled 'Global Issues and Financing for Achieving Sustainable Development Goals' is a unique research effort to analyze the current frontline global issues that is affecting the global economies at large. In these days of global crisis, the COVID-19 global pandemic which has emerged, has become not only a global health crisis but also a global humanitarian crisis. The research has made an attempt to study and analyze the cross cutting global issues including the present global pandemic which has taken a serious toll on humanity, but has also affected the various sectors of the global economies such as health, humanitarian, economic, social, geopolitical, environment etc., and other related crosscutting issues which are vital determinants and key indicators in achieving the Sustainable Development Goals(SDGs). The paper also dwells into the aspect of global financing issues keeping in mind and including finding ways and means for containment of the present global health pandemic by looking into the various aspects of financing needs of the economies to make these economies come out of such serious economic shocks that has resulted and affected these economies due to the outbreak of COVID-19. The research paper also covers and studies other aspects of the global economies such as the Addis Ababa Action Agenda(AAAA) on cross cutting initiatives to develop and built-in synergies for achieving the SDGs, monitoring by the Inter-Agency Task Force on Sustainable Development and the Financing for Global Sustainable Forum(FfSD), upcoming events planned by FfSD, Global issues for FfSD Forum, ECOSOC and its role on International Cooperation in Tax Matters, Global Economic Governance, External Debt, Innovative Financing for Sustainable Development including Inclusive and Local Finance, Global Investors for Sustainable Development Alliance, key messages conveyed by the United Nations in their report on Financing for Global Sustainable Development 2020, important statements made by global experts of United Nations on issues pertaining to financing for achieving SDGs, COVID-19 and its impact on humanity in terms of human crisis, global health crisis and concerns, socio-economic and environmental aspects for sustainable long-term financing in various 
economies including the undeveloped LLDCs, SIDSs, African $\&$ Caribbean economies and the developing economies. The role of international multilateral institutions such as the World Bank IMF, IFC, MIGA and other global financing institutions are of paramount importance in terms of financing these economies to come out of the global pandemic at the first instance and then in stabilizing these economies in the long-run. The important policy considerations and conclusions drawn from the research study is that the WHO and United Nations including other multilateral financing institutions need to work in tandem not only to aid these economies to come out of the global pandemic, but also to strike a balance in terms of achieving the long-term SDGs slated by UN which are key performance indicators and determinants in achieving the SDGs in these economies. Finance is the life blood of all economies and the need of the current global humanitarian and health crisis calls for serious action in terms of long-term financing to these economies to come out of the global crisis and to sustain these economies in the long-run.

\section{REFERENCES}

2020 Development Cooperation Forum, United Nations, New York.

Addis Ababa Action Agenda of the Third International Conference on Financing for Development, United Nations, New York, 2015.

Concept Note (Draft) on SDG Investment Fair 2019, “Closing the SDG Investment Gap”, April 2019, United Nations, New York.

COVID-19 Report of United Nations Department of Global Communications (DGC), Funding the fight against COVID19 in the World's poorest countries, March, 2020, United Nations, New York.

Cross-Cutting Issues for Sustainable Development, March 2020, United Nations, New York.

Financing SDGs 4, 8, 10, 13 and 16: Perspectives from the 2019 Financing for Sustainable Development Report, Financing for Sustainable Office, UNDESA, New York.

FSDR 2019 ODA Update Financing for Sustainable Development Report, UNDESA, New York, April 2019.
FSDR 2020 Press Release, April 9, 2020, United Nations, New York.

FSDR 2020, Inter-agency Task Force on Financing for Development, UNDESA, New York.

Global Policies for the Decade of Action Financing for Sustainable Forum April, 2020, United Nations, New York.

HLPF Side Event of the Inter-Agency Task Force on Financing for Sustainable Development Report 2019, United Nations, New York.

Informal Technical Briefing on the 2020 Financing for Sustainable Development Report, March, 2020, United Nations, New York.

Note by UN Secretary General on Financing for Sustainable Development, ECOSOC Forum on Financing for Development follow-up 15-18 April, 2019, United Nations, New York.

Policy Brief No.59, COVID-19, UNDESA, New York.

Report of the Economic and Social Council Forum (ECOSOC) on Financing for Development follow-up, April 30, 2019, UNDESA, New York.

Report of UN Secretary General on 'International Financial System and Development 15 July, 2019, United Nations, New York.

Report on Shared Responsibility, Global Solidarity: Responding to the Socio-Economic Impacts of COVID-19, March 2020, United Nations, New York.

Terms of Reference of IATF (Inter Agency Task Force) on the follow-up to the Financing for Development Outcomes and the Means of Implementation of the 2030 Agenda for Sustainable Development, 2019, United Nations, New York.

UN Secretary General Observations on Report of UN on Financing for Sustainable Development Report 2019, United Nations, New York.

UN website (www.un.org)

United Nations Press Release, Financing for Sustainable Development Report, 2019, 4 April, 2019, United Nations, New York.

Upcoming events to be conducted by FfSD Forum during 2020, FSD, UNDESA, New York.

WESP Report 2019, UN. 